\title{
3D printing as a diagnostic tool for congenital malformation in a brachycephalic dog
}

\author{
Luiz Felipe Souza de Lima ${ }^{1 *}$ Milena Mendes de Arruda Campos ${ }^{2}$ \\ Anna Julia Brandão Paes de Barros ${ }^{2}$ (D) Gabriela Cardoso Batista ${ }^{1}$ \\ Lorena Tavares de Brito Nery Jaworski ${ }^{1}$ Paloma Moraes Lobo ${ }^{1}$ \\ Antonio Henrique Kuczmarski ${ }^{1}$ Roberto Lopes de Souza ${ }^{1}$
}

'Programa de Pós-graduação em Ciências Veterinária (PPGVET), Hospital Veterinário Universidade Federal de Mato Grosso (UFMT), Cuiabá, MT, Brasil.

${ }^{2}$ Faculdade de Medicina Veterinária (FAVET), Universidade Federal de Mato Grosso (UFMT), 78060-900, Cuiabá, MT, Brasil. E-mail: luizcruella@gmail.com. "Corresponding author.

ABSTRACT: Congenital anomalies are hereditary or acquired, and their location and intensity are determining factors for the survival of animals. Some cases are rare, often unidentified, poorly reported and of unknown etiology. This paper reports a congenital malformation in a French bulldog, demonstrating the importance of accurate diagnosis for surgical decisions. The use of new technologies such as computed tomography and rapid prototyping enables the analysis of morphofunctional changes, resulting in excellent results for clinical cases in which it is difficult to identify and scale the anatomical deformities. Through this feature, it is possible to accurately recreate anatomical structures of interest, enabling greater assertiveness in deciding the treatment to be established, whether surgical or not. Castration of animals that survive this condition due to hereditary etiology is recommended.

Key words: French bulldog, CT scanner, rapid prototyping.

Impressão 3D como ferramenta de diagnóstico para malformação congênita em cão braquicefálico

RESUMO: Anomalias congênitas possuem caráter hereditário ou adquirido, sendo que sua localização e intensidade são fatores determinantes para a sobrevivência do animal. Algumas são raras, muitas vezes não identificadas, pouco relatadas e com etiologia desconhecida. O presente trabalho registra um caso de malformação congênita em um bulldog francês, demonstrando a importância do diagnóstico preciso para a decisão cirúrgica. A utilização de novas tecnologias como tomografia computadorizada e prototipagem rápida possibilitam a análise de alterações morfofuncionais, tendo ótimo resultado para casos clínicos em que há dificuldade em identificar e dimensionar deformidades anatômicas. Através desse recurso é possivel recriar com precisão estruturas anatômicas de interesse, possibilitando maior assertiva na decisão do tratamento a ser estabelecido, sendo ele cirúrgico ou não. É recomendada a castração dos animais que sobreviveram a essa condição, devido a etiologia hereditária.

Palavras-chave: Bulldog francês, tomografia computadorizada, prototipagem rápida.

Phenotypic characteristics that correspond to morphology, behavior and physiology are transmitted between races and are susceptible to mutations, whether or not they result in disease. Brachycephalic dogs, including the French bulldog breed, are susceptible to obstructive respiratory brachycephalic syndrome, which has clinical signs, wheezing, tracheal hypoplasia, and gastrointestinal injuries (choking, nausea, regurgitation, and vomiting); idiopathic megaesophagus; fetal hydrops and vertebral malformations (ALVES et al.,
2013; OECHTERING, 2010). Studies regarding malformations are crucial for developing more accurate studies and treatments on the subject.

Considering that conventional radiographic examination does not provide detection of complex abnormalities, computed tomography and rapid prototyping are associated tools that allow accurate investigation by providing complementary notions of the anatomical structures involved. These technologies are currently being applied to presurgical training and planning, especially in 
the areas of neurology, traumatology, oncology, infectious processes and congenital abnormalities, enabling the definition of the best treatment protocol to be established (BORDELO et al., 2018), as well as the correlation of morphological changes with the clinical situation of each patient (BORDELO, 2018), in addition to providing the spatial dimensioning of the area of interest. Because they are noninvasive techniques, they provide exploration of different tissues, contributing to the quality of the diagnosis without harming the animal (LORIGADOS; PINTO, 2013). This article focuses on a malformation linking the trachea, esophagus and adjacent areas in a male French bulldog puppy using CT and PR techniques to aid the diagnosis and prognosis.

The subject was admitted to the Veterinary Hospital of the Universidade Federal de Mato Grosso Cuiabá: a 4-month-old male French bulldog, weighing $5.5 \mathrm{~kg}$, with vaccination and updated deworms and suspected cleft palate and persistent aortic arch. According to the tutor, since the beginning of solid eating, the patient always displayed regurgitation, sneezing and choking after meals, with gradual weight loss. During the physical examination, it was found that there was no cleft palate or cleft lip. Blood count and biochemical tests were performed, and the animal was clinically healthy. Afterwards, the animal was subjected to a simple radiographic examination with RAICOm SH300D ${ }^{\circledR}$ equipment in the laterolateral and ventrodorsal projections, and the results of the examinations were not conclusive. Thus, contrastenhanced radiography via the barium esophagogram technique was performed in the laterolateraland ventrodorsal. As a result, images suggestive of slight accumulation of contrast in the cranial part of the esophagus were also inconclusive.

For a more accurate diagnosis, a helical CT dual scan was performed using SOMATON Spirit ${ }^{\circledR}$ equipment under the following protocol: bone window capture, adult skull area, $512 \mathrm{~mm}$ FOV, 1.5 mm slice uptake with $1 \mathrm{~mm}$ overlap, with the values of $\mathrm{kVp}$ and $\mathrm{mAs}$ defined by the equipment itself. The captured images suggested a connection between the esophagus, trachea and adjacent soft tissues due to the natural radiodensity contrast between soft tissues and air (Figure 1). Results demonstrated nasopharyngeal obliteration in the region of the pterygoid foramen by soft tissues, associated with loss of soft palate

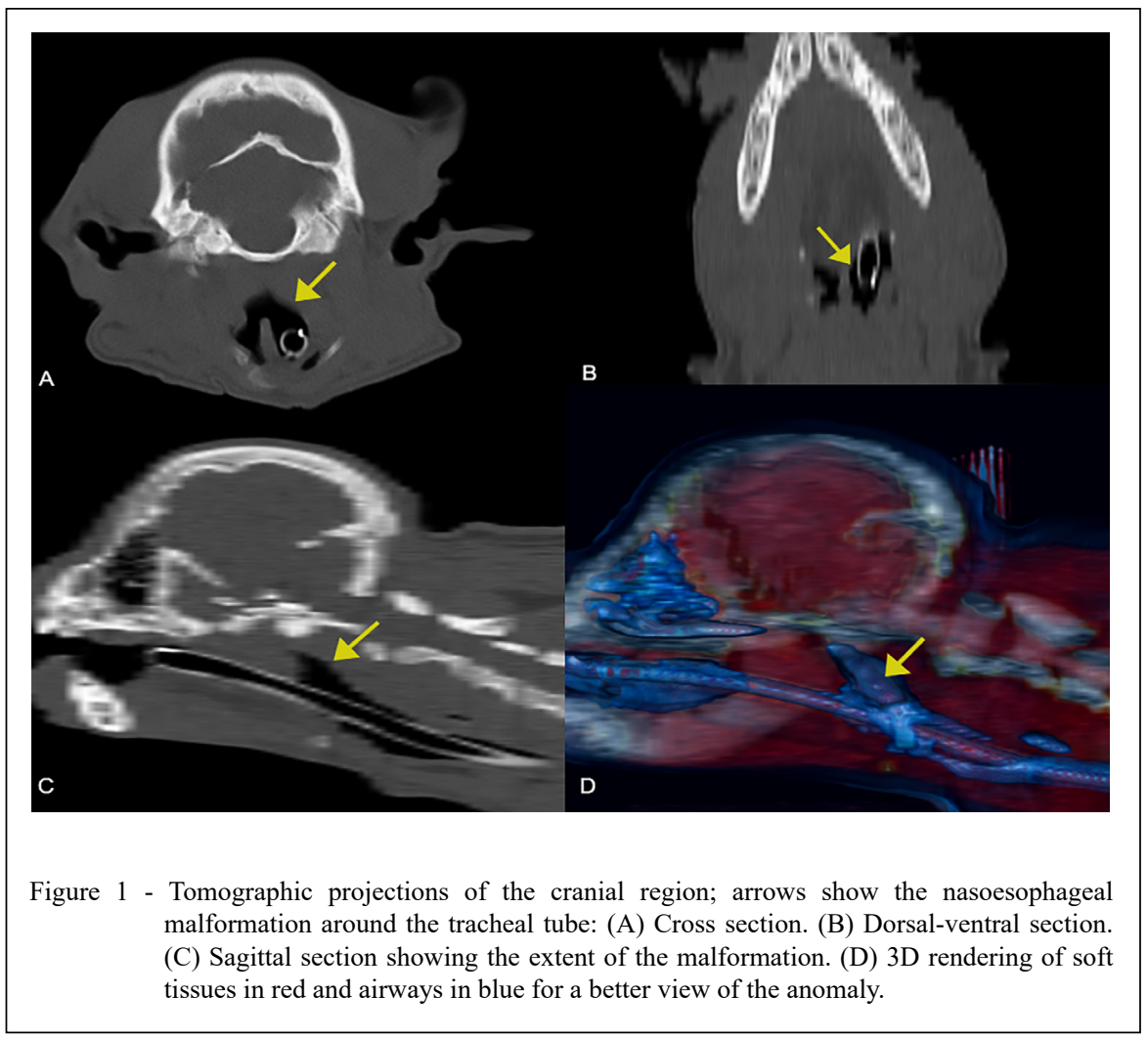

Ciência Rural, v.50, n.8, 2020. 
and oropharynx distinction, without evidence of post-contrast enhancement. The CT scan allowed the visualization of the abnormal area in the tomographic slices but did not provide a spatial understanding of the affected area, making planning for surgical correction unfeasible due to its unspecific shape. However, tomography made it possible to measure the largest points of the anomaly, with a maximum height of $23.857 \mathrm{~mm}$, width of $27.043 \mathrm{~mm}$ and length of $78.331 \mathrm{~mm}$. To elucidate this area of interest, tomographic data in the free software Invesalius ${ }^{\circledR}$ were used to segment the structure using the Hounsfield density threshold. Then, rapid prototyping was performed using GTMax3D Core A3v2 equipment with a biodegradable PLA (polylactic acid) filament to reproduce the physical biomodel of the anomaly at full size (Figure 2). With the performance of 3D printing, it was possible to clearly determine the shape dimensions and the extent of the malformation, thus providing material necessary for better risk assessments and success rates, guiding the decision of whether to perform corrective plastic surgery.

Due to the location of the malformation, the extremely invasive access and the unfavorable prognosis, it was decided not to subject the puppy to corrective surgery. However, while awaiting the results of imaging and $3 \mathrm{D}$ printing, the patient was being treated with a therapeutic protocol for megaesophagus, i.e., changes in eating habits, with lower amounts and a greater frequency, always providing solids and liquids in high areas in order to lift its head for ingestion. The patient had a considerable decrease in choking and sneezing instances, promoting progressive weight gain and better quality of life.

Congenital malformations are common in commercial dogs and are more prevalent in brachycephalic breeds such as the French bulldog (ALVES et al., 2013; OECHTERING, 2010). Dermatological diseases in the gastrointestinal tract and those considered nonspecific represent the main reasons for clinical care in French bulldogs, providing evidence that this breed is prone to several congenital morphofunctional dysfunctions. This is mainly due to the intensification of the commercial breeding of pets, without the concomitant search for avoiding the transfer of frequently observed defects to future litters, in addition to the practice of crossing between relatives, promoting inbreeding and increasing the chances of puppies presenting congenital anomalies (ARGENTA et al., 2018; OECHTERING, 2010).

In the present research, the rapid prototyping and computed tomography made it possible to accurately materialize the anatomical malformation area, as well as to visualize structures that were hidden or barely visible in the complementary exams (LORIGADOS; PINTO, 2013; BORDELO, 2018), leading to the diagnosis of a congenital malformation that interconnects the trachea and the esophagus, affecting adjacent areas of soft tissue and creating air pockets along the oropharyngeal region. This hollow structure is responsible for choking, vomiting and breathing

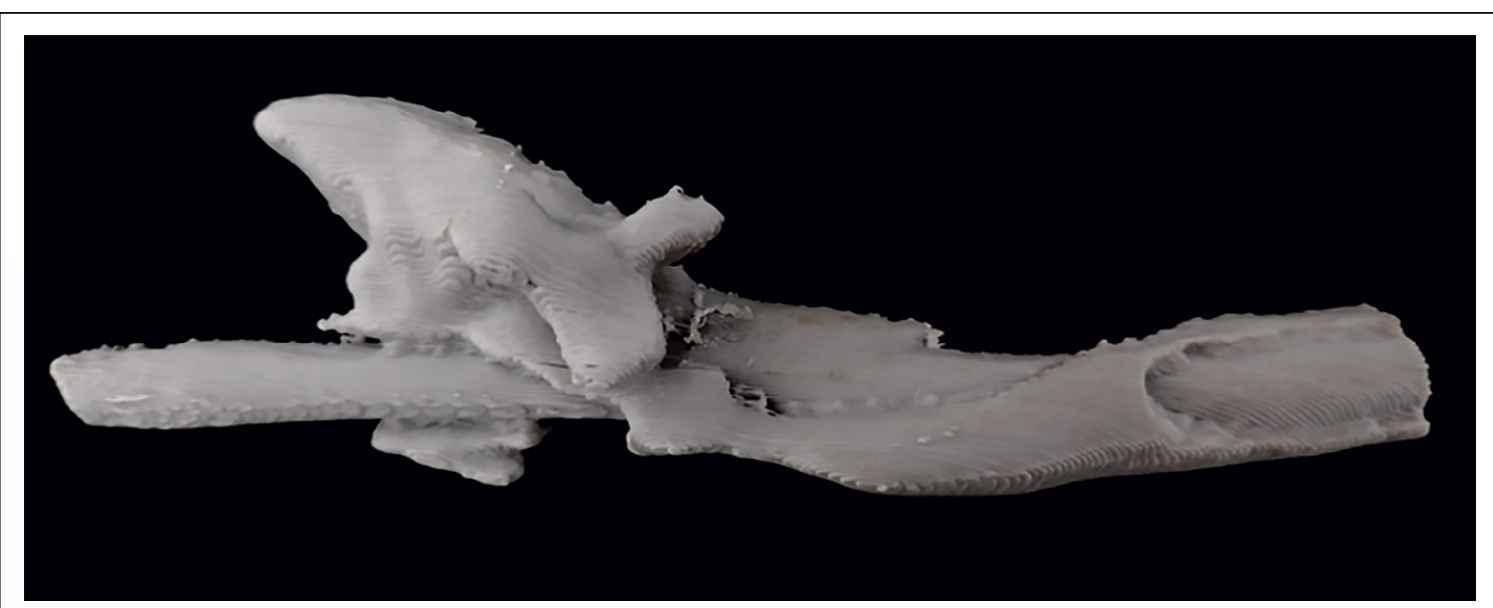

Figure 2 - Physical biomodel resulting from 3D printing, showing the anomaly and its spatial distribution around the tracheal tube. 
difficulties since there is no tissue separating the ducts (ALVES et al., 2013).

The presurgical planning of complex cases, with the aid of modern diagnostic methods, is intended to significantly reduce surgery time and anesthesia time and to reduce the number of mistakes made due to the lack of information about the affected area (BORDELO et al., 2018). With proper planning and accurate diagnosis (BORDELO et al., 2018; HARRYSSON et al., 2003), which on this occasion were CT and $3 \mathrm{D}$ printing, the malformation was found to be in a region of difficult access, with little soft tissue for manipulation, making surgical intervention unfeasible due to the ineffective execution of corrective techniques. This ensured that the patient was not subjected to ineffective exploratory surgery, avoiding a painful procedure and unfavorable surgical prognosis.

Although, the animal had a morphological abnormality, this in turn was not incompatible with life, and due to the age of the animal, it was possible that there would be biological correction or adaptation of the animal to this condition. During the patient's last care, approximately 60 days after the diagnosis, the tutor reported that the animal had experienced significant improvement, with rare episodes of regurgitation and sneezing, thus promoting progressive weight gain. Thus, a good outcome was achieved with supportive clinical treatment for megaesophagus.

The morphological understanding of anatomical abnormalities in veterinary medicine is an essential element to define the protocol to be adopted. Since this understanding is usually achieved only through necropsy, it is not viable for surgical planning in vivo. This report aimed to assess new technologies to better understand and reproduce anatomical structures digitally and physically, favoring the best surgical choice.

\section{DECLARATION OF CONFLICT OF INTERESTS}

The authors declare no conflict of interest. The founding sponsors had no role in the design of the study; in the collection, analyses, or interpretativos of data; in the writing of the manuscript, and in the decision to publish the results.

\section{AUTHORS' CONTRIBUTIONS}

The authors contributed equally to the manuscript.

\section{REFERENCES}

ALVES, N. M. et al. Megaesôfago congênito em cão. Pubvet, 2013. v.7, n.23, p.1-9. Available from: <https://www.pubvet.com. br/uploads/ce04c52859ab25fb633f78b068a23bef.pdf $>$. Accessed: Dec. 10, 2019.

ARGENTA, F. F. et al. Alterações congênitas do coração e dos grandes vasos em cães. Pesquisa Veterinária Brasileira, 2018. v.38, n.6, p.1184-1189. Available from: <https://www.scielo.br/ pdf/pvb/v38n6/1678-5150-pvb-38-06-1184.pdf >. Accessed: Jan. 08, 2020. doi: 10.1590/1678-5150-PVB-5457.

BORDELO, J. P. A. et al. A 3D printed model for radius curvus surgical treatment planning in a dog. Pesquisa Veterinária Brasileira. v.38, n.6, p.1178-1183, 2018. Available from: $<$ https:// www.scielo.br/scielo.php?script $=$ sci abstract\&pid $=$ S0100736X2 $018000601178 \& \operatorname{lng}=\mathrm{pt} \& n \mathrm{~mm}=\mathrm{iso} \& \mathrm{t} \ln \mathrm{g}=\mathrm{en}>$. Accessed: Dec. 20, 2019. doi: 10.1590/1678-5150-pvb-5209.

HARRYSSON, O. L. A. et al. "Rapid prototyping for treatment of canine limb deformities", Rapid Prototyping Journal, v.9 Issue:1, pp.37-42, 2003. Available from: < https://www.researchgate. net/publication/235272695_Rapid_prototyping_for_treatment of_canine_limb_deformities $>$. Accessed: Nov. 15, 2019. doi: $10.1108 / 13552540310455647$.

LORIGADOS, C. A. B.; PINTO, A. C. B. F. Tomografia computadorizada do encéfalo do cão: aspectos da normalidade e correlação anatômica. Arquivo Brasileiro de Medicina Veterinária e Zootecnia, 2013. v.65, n.3, p.729-734. Available from: $<$ https://www.scielo.br/pdf/abmvz/v65n3/18.pdf $>$. Accessed: Nov. 15, 2019. doi: 10.1590/S0102-09352013000300018.

OECHTERING, G. U. Brachycephalic syndrome-new information on an old congenital disease. Veterinary Focus, 2010. v.20, n.2, p.2-9 Available from: <https://www.cabdirect.org/ cabdirect/abstract/20103218464>. Accessed: Nov. 20, 2019. 